【カテゴリーI】

日本建築学会計画系論文集 第84巻 第765号, 2369-2377, 2019年11月

J. Archit. Plann., AIJ, Vol. 84 No. 765, 2369-2377, Nov., 2019 DOI http://doi.org/10.3130/aija.84.2369

\title{
3D Isovist Graph 解析システムの開発と応用 DEVELOPMENT OF SYSTEM FOR 3D ISOVIST GRAPH ANALYSIS
}

宮崎 慎也*1

Shinya MIYAZAKI

\begin{abstract}
Isovist graph has been originally developed for $2 \mathrm{D}$ space analysis technology of urban and architectural space. This paper develops the isovist graph analysis technology from 2D to 3D for more clear evaluation of 3D environment and shows the simulation method of 3D isovist graph to analyze 3D environment more realistically than 2D. First, it is applied to a virtual 3D space model to show the difference between 2D and 3D simulation. Then it is applied to the real 3D space model of a university campus which includes height difference in its geography for validation of practical design use.
\end{abstract}

Keywords : Isovist Graph, Sight Depth, Depth-Map, 3D Space, Graph Theory, Campus Design イソビスト・グラフ, 視深度, デプスマップ，3 次元空間, グラフ理論, キャンパスデザイン

\section{1. はじめに}

\section{1 研究の背景}

isovist は空間内に存在する人間の可視領域のことで, 古くは Benedikt らが解析的にアプローチした研究 ${ }^{1)}$ が見られ, 国内外で多 数の応用研究が報告されている. 日本においても, 視深度を用いて 近代住宅作品の空間を評価する研究 ${ }^{2)}$ などの応用研究が報告されて いる. isovist が建築空間や都市空間内に存在する人間の視線を, 連 続的に広がる空間領域として捉えるのに対して, isovist graph は人 間の視線を離散化して解釈することで，グラフ理論の指標を用いた 様々な評価ができることが利点である．isovist graph についてはこ れまで, B.Hillier らの Space-Syntax に代表されるような理論的な 研究 ${ }^{3)}$ や, A.Turner ${ }^{4)}$ などによる応用研究が進められている. シミ ユレーション手法も確立されており,「Depth Map」5) などの汎用ア プリケーションによって，手軽に様々なシミュレーションが行うこ とが可能となっている.

\section{2 研究目的}

本研究では, これまで行われて来た isovist graph の研究を 3 次元 空間に展開し応用寸ることを目的とする. 3 次元の isovist を扱った 研究としては, 可視領域を立体角やヴォリュームとして扱ったもの 6)778) など比較的多くの報告があるが，これらは人間の可視領域を 3 次元的なヴォリュームとして解釈したもので, 可視領域のシークエ ンシャルな変化や, 建築物による視線の遮蔽が都市空間に与える影 響など，景観的な観点に着目したものがある。これらの研究の特徵 は，可視領域のヴォリュームの幾何学的な特徵や量を評価指標とし
て利用している点であるが，視線のネットワーク的な観点は考慮さ れていない.ネットワーク的な観点の研究, 寸なわち 3D isovist graph の研究については，建築物の吹き抜け空間を対象にしたケーススタ ディーの研究 9) などが見られるが報告が少なく, 解析技術の確立や, 応用研究が待たれているところである. 本研究は, 3D isvist graph の 基礎研究 ${ }^{10}$ に対して, 定量的な検討と応用のためのケーススタディ 一を加えてデザインツールや空間評価手法として応用する展開を試 みるものである。

2D isovist においては，人間の視線は地平面と平行な一つの面上に 通ると仮定されている，都市スケールを対象と寸る空間評価などで は，地形の高低差などの 3 次元情報を捨象することで，よりシンプ ルに広域的な空間の特徵が記述できる利点を持つ，一方，歩行空間 など，よりヒューマンスケールの空間を評価する場合は，斜面，坂 道，段差などの地形が，視線の抜けや遮断に与える影響は大きくな る.このような場合, 3 次元の情報を捨象することによって, 歩行 者が実際に体験する空間を実体に即して評価することができなくな る恐れがあり，3 次元情報を考慮した空間評価が必要になる.

本研究では, 3 次元の地形上に位置する人間同士の視線の関係を 3D isovist graph としてモデル化する. 3 次元の幾何学情報は 2 次元 と比較して計算が煩雑になる問題があるが，isovist を 3 次元上の視 線のネットワークとして扱うことによって，3 次元幾何学を扱う計 算負荷を軽減でき，さらにグラフ理論の指標を利用したネットワー ク評価も可能である. 2D isovist graph では視点の高さがすべて均一 の仮定であるのに対して，標高差のある地形では，地形の変化に沿 
つて視点の高さが変化すること, また, 建築物などの構造物だけで なく, 地形自身が視線の遮蔽要素となることが, 大きく異なる. 2D, 3Dの 2 つの isovist graph を比較しながら, 3D isovist graph の有効性 について，具体的なモデルを用いて検証していく.

\section{2. 研究方法}

\section{1 研究の流れ}

本研究では, 3D isovist graph のモデル化方法, グラフの評価指標, 解析フローを示し, その後, この解析システムを仮想の 3D 地形モ デルに適用しケーススタディーを行う．2D isovist graph と 3D isovist graph, それぞれの解析結果を検証し, その違いを明らかにする.さ らに，高低差のある F 大キャンパス空間へモデルを応用し，2D と 3D isovist graph の違いを明らかにするとともに，キャンパスデザイ ンの観点から有用性を検証する。

近年, 多くの大学がキャンパスマスタープランを策定し, キャンパ スの軸線, 動線計画, 景観計画, 建築物配置計画, オープンスペース 計画を行っている. 歩行者の isovist はこれらに関係する重要なキャ ンパスデザインの評価指標の一つであるが, $\mathrm{F}$ 大キャンパスのように, 高低差のある地形に建築物が複数配置される場合, 地形の影響を, 感 覚的, あるいは経験的に捉えることは困難であり，3D isovist graph を 客観的かつ定量的にデザインを評価するッールとしても応用できる 可能性を示す.

\section{$2.23 D$ isovist graph のモデル化}

isovist graph は, 人間の視線の関係をグラフによって表現したも のである. 地面の上に人間が配置されていると仮定し, 人間の目線 の高さ位置注 1) にノードを配置する. すべてのノードに対する完全 グラフを作成し，これらの視線が建築物や地形によって遮断される エッジを除いたものが，3D isovist graph となる．2D isovist graph に おいては, 建物のみが視線の遮蔽要素であるが, 3D isovist graph で は, 建物以外に地形自身が視線の遮蔽要素になり, 視点の高さも地 形に沿って変化することが特徴である(Fig.1).

これまで, 3D isovist に関連する研究としては, 視点を中心として, 放射状に広がる視線ベクトルを対象とした研究 11) 12) 13)などがある。 これらの研究は, 視点を中心として立体的に広がる 3 次元的な視界 領域や視対象への視線の抜けについて記述している. 一方, 本研究 は2Dの isovist graphを3Dに拡張し, 起伏のある地形におけるアイ レベル上の視点と視線の関係に着目寸るところに特徴がある. 天空 に向けての視界の広がりなどの経路選択には関わりにくい視線べク トルは考慮せず，人間が経路選択の主な手がかりとしているアイレ ベルの空間の視線のつながりのみに注目することで対象領域の空間 検索性に着目して視線のネットワーク構造を明らかにする. 前者が ある特定の視界の広がりや, 特定視対象が見えるか否かを扱うのに 対して, 本研究は起伏のある地形におけるアイレベルの領域全体の 空間検索性を評価することに特徴がある.
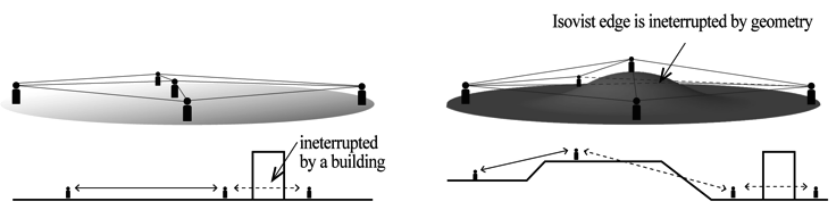

$\begin{array}{ll}\text { (a) } 2 \mathrm{D} \text { isovist graph on flat geometry } & \text { (b) } 3 \mathrm{D} \text { isovist graph on geometry with height difference }\end{array}$ Fig.1 Comparison of 2D and 3D isovist graph

\section{3 評価指標}

本研究では, Neiborhood-Size (NS), Mean-Distance (MD), MeanStep-Depth (MSD), の 3 種類の指標を用いて 3D isovist graph を評 価する.グラフの分析においては各ノードの 3 次元の空間位置情報 は捨象されるが，それぞれのノード間のエッジ重みに，3 次元上の 距離を与え，実空間の距離を解析結果に反映する.

\subsection{1 近隣サイズ : Neiborhood-Size (NS)}

NS はグラフの任意のノードに接続するエッジ数であり, isovist graph においては，実空間において人間がある空間に位置する際の 可視領域の広さを近似的に示寸指標になる. グラフ $G=(V, E)$ の任 意のノードを $v_{i}$ とし, $v_{i}$ の隣接エッジ数を $k_{i}$, グラフ $G$ のノード 総数を $N$ として, NS を隣接エッジ数の総ノード数に対する割合 の形で以下のように定義する.

$$
N S_{v_{i}}=k_{i} /(N-1)
$$

この指標はグラフ理論における最も一般的な指標であるが, isovist graph においても, 任意の視点における視界の領域の広さを示寸值 となる注 2). 值が 1 に近づくほど, より大きい可視領域をもつ視点 であることを示す。

既往研究 11) 12) 13)では, ランドマークや樹木など特定の視対象が 設定される場合や, 視点からの外部空間への視線の抜けなどを評価 する場合など, いずれも視点と対象が区別されている. 本研究では, アイレベルの視点相互のつながりを評価することに特徵があり, 領 域全体内の視線のネットワークの全体的評価が可能となる.

例えば, キャンパス外部にランダムに人間が分布している場合に, NS の值が高い場所は, その位置から見渡せる人間の数が多く, 同 時に多数の人間から見られる位置であることを示している。また， NS の平均值は，キャンパス外部空間の視覚的一体感を評価する指 標としても参考にできる.さらに, 本研究では $3 \mathrm{D}$ の地形を考慮す ることで，2D と比較し，より実態に即した空間評価を行う.

\subsection{2 平均最短距離: Mean-Distance (MD)}

MD はあるノードからその他す心゙てのノードへの最短経路距離 の平均值である. グラフ $G=(V, E)$ の任意の 2 つのノード $v_{i}, v_{j} \in$ $V$ の最短経路のエッジ数を $d\left(v_{i}, v_{j}\right)$ とし、 $v_{i}, v_{j}$ 間の最短経路の平 均のエッジの重みを $\bar{w}\left(v_{i}, v_{j}\right)$ とした時 $v_{i}$, と $v_{i}$,を除く全てのノード 間の最短平均距離 $M D_{v_{i}}$ は以下のように表される.

$$
M D_{v_{i}}(G)=\sum_{j=1 ; j \neq i}^{N} d\left(v_{i}, v_{j}\right) \bar{w}\left(v_{i}, v_{j}\right) /(N-1)
$$

MD は空間内のある視点から他の全ての視点までの平均距離で あり，一般的には空間の中心ほど小さい值となる.

グラフ理論においては, 近隣サイズは次数中心性, 平均最短距離 は近接中心性とも呼ばれるが, 次数中心性が一般的に想像される中 心とはしばしば異なること, これに対して, 近接中心性はグラフの 中心部分が高くなることが知られており ${ }^{14)}, \mathrm{MD}$ にってキャンパ スの視線のネットワークの中心性を把握することができる.

例えば, キャンパスにおいて, 近接中心性の高い場所は, どこか らもアクセスしやすく, 視線が通る目立ち易い場所であり, キャン パスの案内板や AED などを配置するのに適した場所といえる注3). 
また, キャンパス計画において建物の配置や動線計画を行う場合, 主要動線と近接中心性が高い場所との位置関係を把握すること, キ ヤンパスの全体的なアクセス性と視認性を定量化して把握するこ と, などに本指標を利用することができる.さらに, 本研究では, 3D の地形を考慮することで, 2D と比較し，より実態に即した空間 評価を行う注 4 ).

\subsection{3 平均階層: Mean-Step-Depth(MSD)}

MSD はあるノードからその他すべてのノードに対する階層深さ の平均值であり, $v_{i}, v_{j}$ 間の最短経路の平均のエッジの重みを $\bar{w}\left(v_{i}, v_{j}\right)=1$ とした場合の, $M D$ の值と同值である.

$$
M S D_{v_{i}}(G)=\sum_{j=1 ; j \neq i}^{N} d\left(v_{i}, v_{j}\right) /(N-1)
$$

MSD は MD とは異なり, ある視点から他のある視点までのエッジ 数を示寸指標であり, 距離に依存しない指標である. 例えば, マン ハッタングリッドのような格子の場合には, $M S D<2$ となり, 1 回 交差点を折り曲がるだけで, 全ての地点を見渡すことができる。ま た, イスラムの都市のような複雑な街路構造の場合には, MSD は大 きくなる.この指標の特徵は, 距離に依存せず, 空間のつながりを 見えるか見えないかで捉えるところにあり, 空間の階層性の深さ (depth) を示す指標である. また，この指標は空間の探索のしやす さ，すなわち空間の検索性を示すものとも捉えることができる.

例えば, キャンパスにおいては, 学会やオープンキャンパスなど 外来者が来訪する機会が多いが, 案内所の位置から各建物まで, 視 線の折れ曲がる位置にサインを配置し誘導する場合, 最もサインの 数を少なくできる案内所の位置が平均階層の最も小さい場所であ る. また, この場所は各建物から見ると, 最も見つけや寸い位置で あるとも言える注 5). MD と同様に MSD の值も，キャンパスの視線 のネットワークの中心性を把握する指標になり, キャンパスの建物 配置や動線計画を考える上での重要な指標となる. さらに, 本研究 では, 3D の地形を考慮することで, 2D と比較し, より害態に即し た空間評価を行う。

\section{$2.43 \mathrm{D}$ isovist graph の解析フロー}

本研究では, 3D isovist graph を解析するための, プラットフォーム を開発する注6). Table 1 に 3Disovist graph の解析フローを示寸. 2D isovist graph では視線のネットワークの構築ための, 完全グラフの枝 切りにおいて，2 次元の線分同士の交差判定が必要になるが，3D isovist graph の場合この枝切りにおいて，3 次元の線分と面との衝突 判定が必要となることが技術的な特徴である. その他のプロセスは, 2D isovist graph と同様の解析フローである. 最短経路の探索にはダイ クストラ法を用い, $M D$ を計測する時のエッジの重みは, 線分の長さ をそのまま付与し，最短経路探索を行う。

\section{Table1 A flow of 3D isovist graph analysis}

\begin{tabular}{l|l}
\hline STEP & PROCESS \\
\hline Step1 & Input of 3D geography and building information as mesh data. \\
\hline Step2 & $\begin{array}{l}\text { Generating nodes on a grid at eye-level and eliminating the } \\
\text { nodes which is included in buildings' volume. }\end{array}$ \\
\hline Step3 & $\begin{array}{l}\text { Making perfect-graph from the nodes which is generated in } \\
\text { Step2. }\end{array}$ \\
\hline Step4 & $\begin{array}{l}\text { Cutting the edges of perfect-graph which are interrupted by } \\
\text { geography and building mesh surface. }\end{array}$ \\
\hline Step5 & $\begin{array}{l}\text { Calculating shortest-path of all pairing combinations of nodes } \\
\text { using Dijkstra's algorithm by steps and distances. }\end{array}$ \\
\hline
\end{tabular}

\section{3. 仮想地形によるケーススタディー}

ここでは，2D と 3D の仮想地形(fig.2)を用いてシミュレーション を行い, 3 つの指標を比較するとともに, 可視化して空間的な分布の 違いについて比較する．2D モデルはフラットな地表上に建築物と して見立てたコの字型のヴォリュームを配置したものである. 3D モ デルは, 右側に山形のスロープがあり, コの字型のオブジェクトには 高さが与えられている.この 2 つのモデルを用いて, 地形が視覚環境 に与える影響を可視化してシミュレーションする.

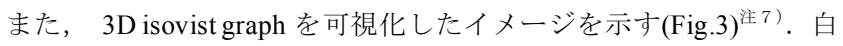
線で示されているのが視線のグラフであり, スロープの勾配に沿っ て, 視点が配置され 3 次元的な視線のネットワーが構築される. 視点 間の間隔は $2,500 \mathrm{~mm}$ に設定し，シミュレーションを行う。

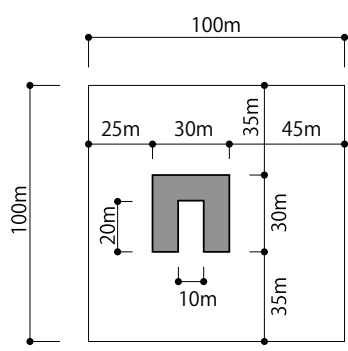

(a) 2D model (flat geography)

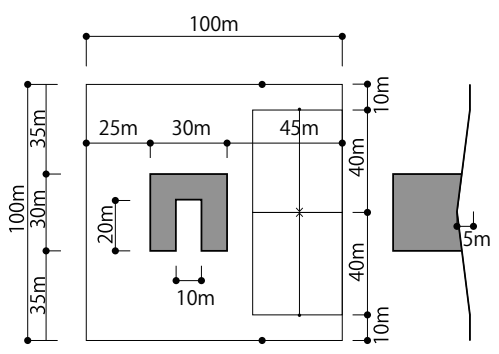

(b) 3D model (geography with slope)

Fig.2 2D and 3D virtual geography model

\subsection{NS : 近隣サイズの比較}

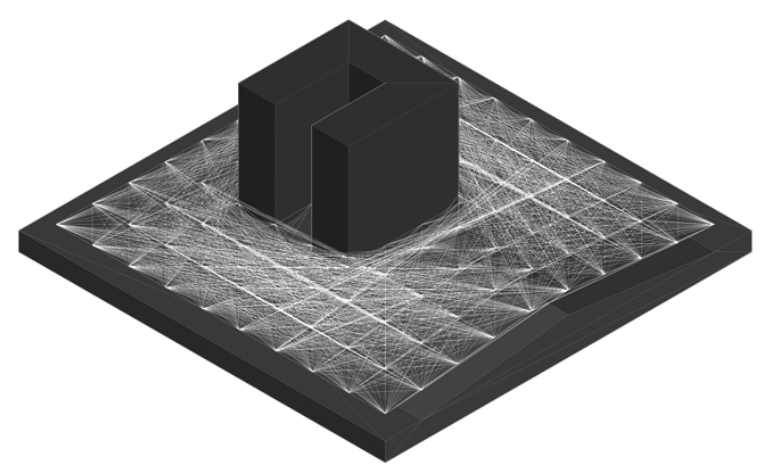

Fig.3 Image of 3D isovist graph in virtual geography model

NS の分布を 2D と 3D のカラーマップで示す(Fig.4(a)(b)). また, NS が最大, 最小となる視点の位置と, それらの視点の隣接エッジを可視 化したものを示す(Fig.4(c)(d)(e)(f)). まず, カラーマップについては, 2D, 3D ともに, コの字型の内側の部分の值が低い. また, 2D と比較 して3D は, 建築物とスロープの間は可視領域が狭く, スロープの稜 線付近の值が高い. これは, 地形によって視点の高さが変化したこと， 地形が視線を遮断すること, の 2 つの要因が重なり合って生じるも のであり，3D のシミュレーションでは 2D では把握できない微妙な 地形の変化による isovist への影響が可視化できる. 最大, 最小とな る視点の位置については, 最大值をとる視点は $2 \mathrm{D}$ と $3 \mathrm{D}$ でほとんど 同地点であるが, 地形に遮断されるため3D 方が值は低い. 最小とな る視点の位置や值は同じとなっている. 


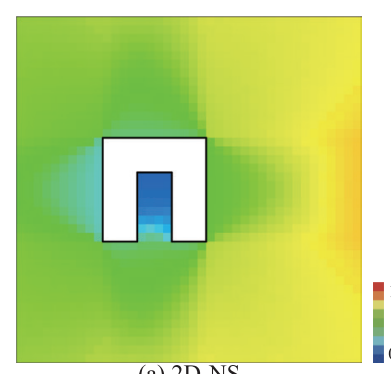

(a) 2D-NS

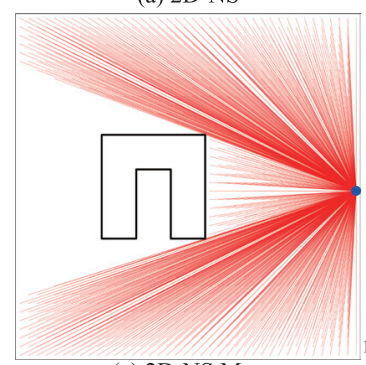

(c) 2D-NS Max

Max $: 0.7876$

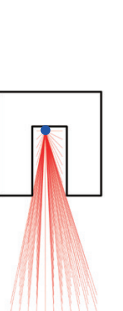

(e) 2D-NS Min

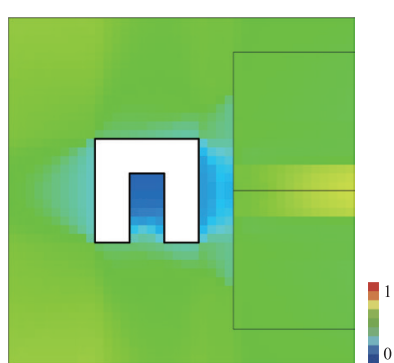

(b) 3D-NS

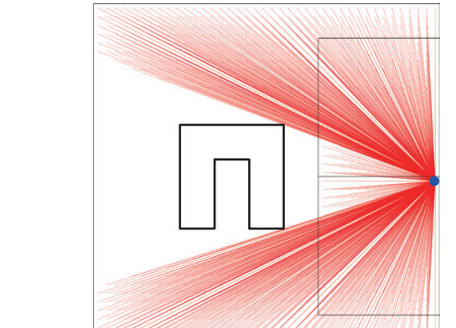

(d) 3D-NS Max

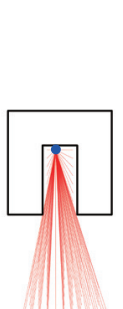

(f) 3D-NS Min

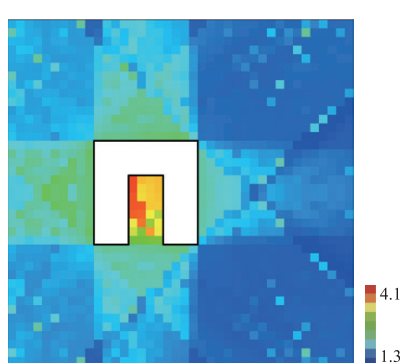

(a) 2D MSD

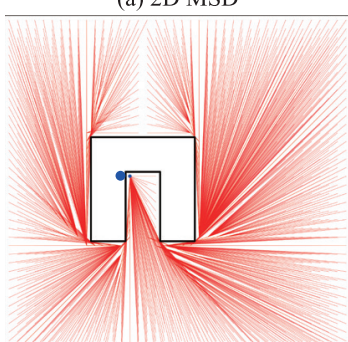

(c) 2D MSD-Max

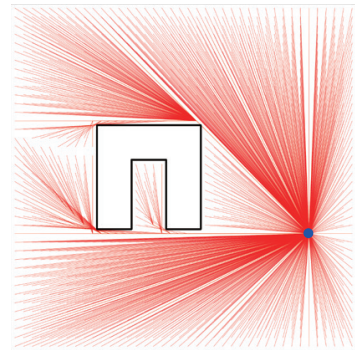

(e) 2D MSD-Min

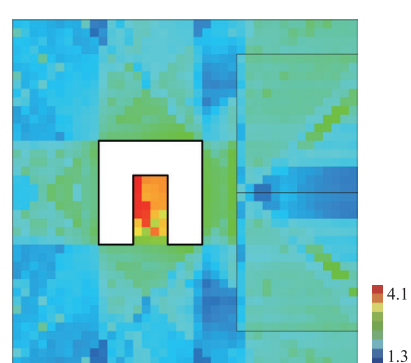

(b) 3D MSD

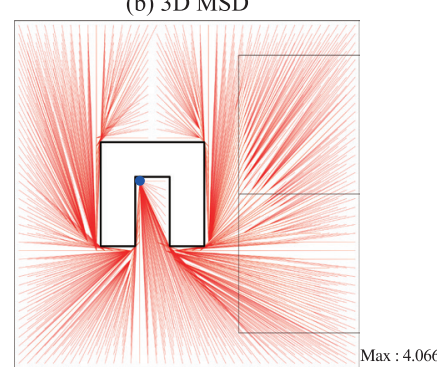

(d) 3D MSD-Max

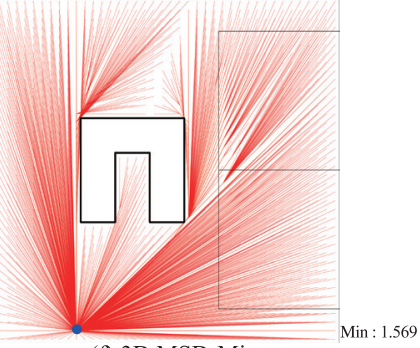

(f) 3D MSD-Min

Fig.4 Result (NS) : Case-study in virtual geography model

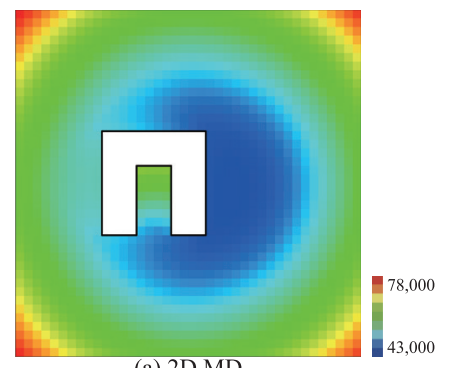

(a) 2D MD

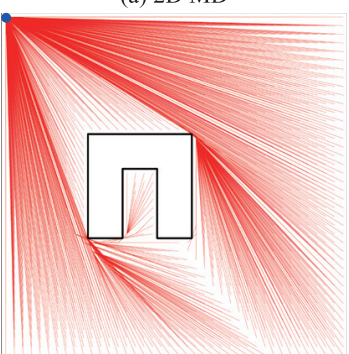

(c) 2D MD-Max

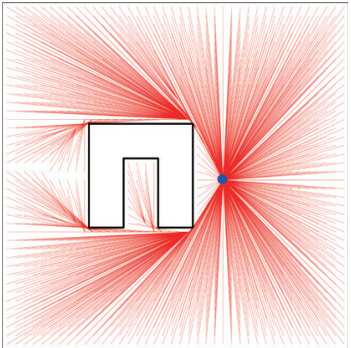

(e)2D MD-Min
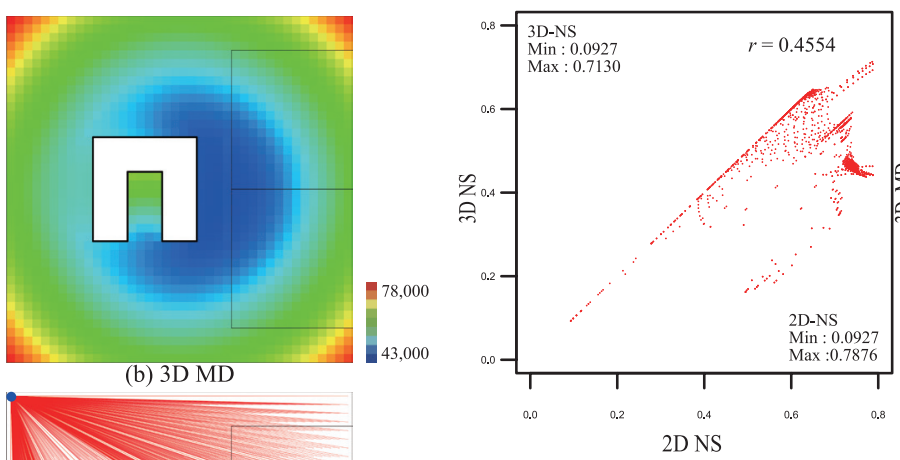

(a)

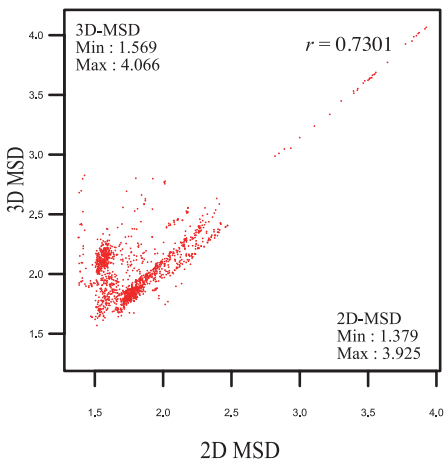

(c)

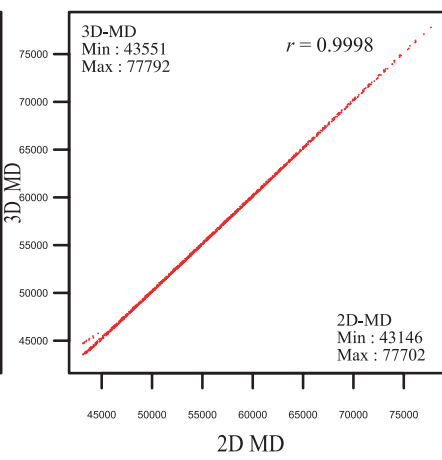

(b)

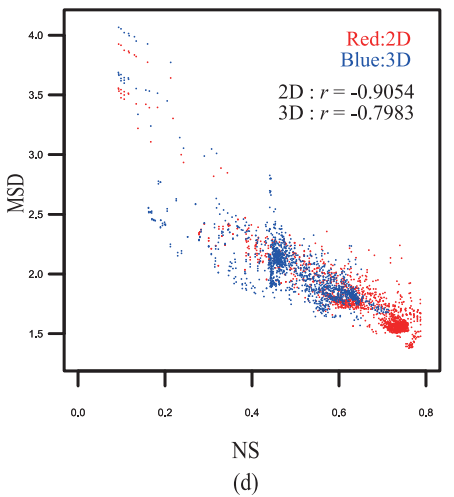

Fig.7 Scatter plots : Comparison of $2 D$ and $3 D$ isovist graph in virtual geography model case-study (NS, MD, MSD)

Fig.5 Result (MD) : Case-study in virtual geography model 


\section{$3.2 \mathrm{MD}$ : 平均最短距離の比較}

$\mathrm{MD}$ の分布を 2D と 3D それぞれカラーマップで示す(Fig.5(a)(b)). $\mathrm{MD}$ の值は，2D と 3D ともに，中心に近づくと低く，遠ざかると高 くなる．色の分布も $2 \mathrm{D}$ と $\mathrm{D}$ でほぼ同じであり，地形の影響はほと んど見られない, また, 最大, 最小となる視点の位置と, 極值をとる 視点からその他の視点への最短経路を示寸 $(F i g .5(\mathrm{c})(\mathrm{d})(\mathrm{e})(\mathrm{f}))$. 最大值 をとる視点は左上の角で同地点であるが，最小值については，地形の 影響を受けるため若干異なり，3D では建築物とスロープの間に最小 值をとる視点が位置する。

\subsection{MSD : 平均階層の比較}

MSD の分布を 2D と 3D それぞれカラーマップで示す(Fig.6(a)(b)). MSD の值を 2D と比較すると，3D は全体的に緑色が多く, 值が高 い. 3D ではスロープの稜線付近が青色で值が低く，スロープを下る に従って緑色に変化し，值が高くなる．また，最大，最小となる視点 の位置と，極值をとる視点からその他の視点への最短経路を示す $($ Fig.6(c)(d)(e)(f))．最大值をとる視点はコの字型の内側で視点は同じ 位置であるが，最小值をとる視点は異なり，地形の影響で極值をとる 位置が変化することが分かる.

\section{4 仮想地形における $2 \mathrm{D} \cdot 3 \mathrm{D}$ モデルの数値比較分析}

2D と 3D のモデルを比較するため, 各視点 $(\mathrm{N}=1448$ 点) について, NS, MD, MSD,それぞれの散布図を示す（Fig.7(a)(b)(c))。また，これ らの, 平均值, 最大值, 最小值, $2 \mathrm{D}$ と 3D の相関係数を Table2 に示 す. Fig.7 と Table2 から, 2D と 3D の数值を比較すると, NS の平均 值は3D の方が低く, MD の平均值は 2D と 3D とでほぼ等しく MSD の平均值は3D の方が高い. それぞれの指標の相関は, MD は $r \fallingdotseq 0.99$ で相関が高く,NS やMSD はそれほど相関が見られないＮＳと MSD の相関関係においては, Fig.7(d)から 3D よりも2D の方が負の相関が 強い，以上より，MDについては地形の影響がほとんどなく，NS や MSD の值は地形の影響が見られると言える.

Table2 Numerical comparison of 2D and 3D isovist graph in virtual geography model case-study (NS, MD, MSD)

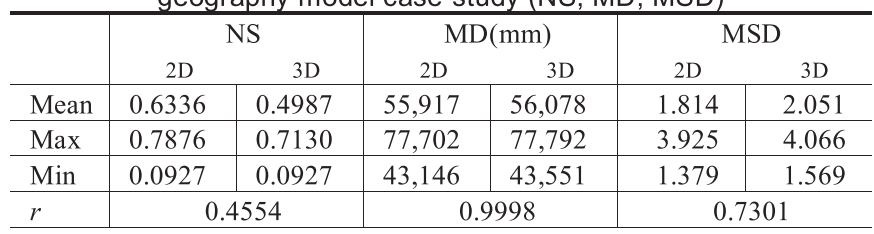

\section{4. 大学キャンパスの地形によるケーススタディー}

ここでは, F 大キャンパスの実際の地形と建築物(Fig.8)のデータを 用いて, 2D と 3D それぞれの場合で，シミュレーションを行う(Fig.9) 注8). 3 つの指標を比較するとともに，可視化して指標の值の分布を

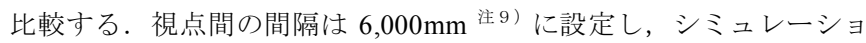
ンを行う。仮想地形と同様に 2D はフラットの地形とし，3D は実際 の地形に合わせて, 高さ $1,000 \mathrm{~mm}$ ごとの等高線を階段状の地盤ヴオ リュームとして表現したメッシュデータを用いる.これらの地盤上 に実態に即して建築物のヴォリームを配置する.なお, キャンパスは 海抜 $16 \mathrm{~m}$ から海抜 $27 \mathrm{~m}$ まで約 $11 \mathrm{~m}$ の標高差があり，中心部は窪みが あり，底の標高は $18 \mathrm{~m}$ である。これらの地形と建築物のモデル対し て, Table 1 の Step4 までのフローを適用する.

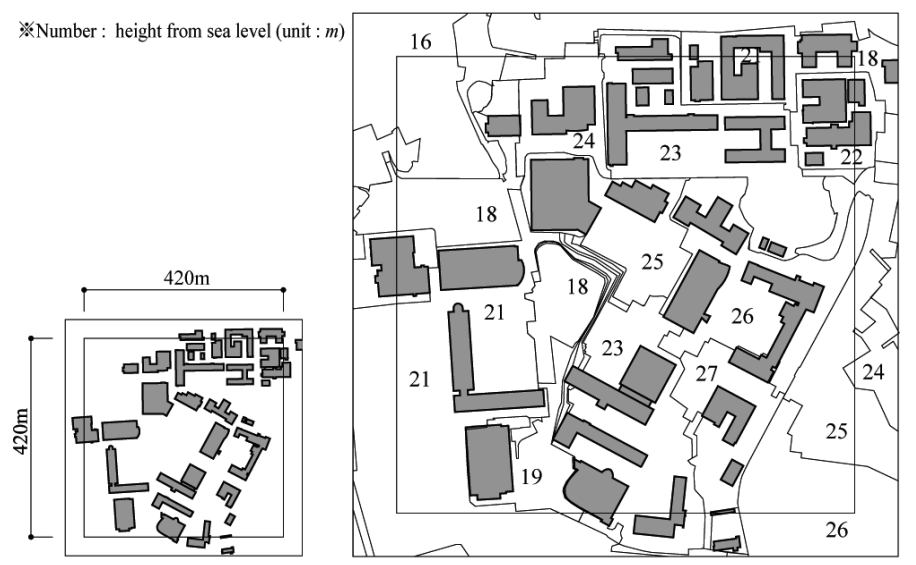

(a) 2D model (flat geography)

(b) 3D model (geography with height differnce)

Fig.8 2D and 3D FU campus geography model

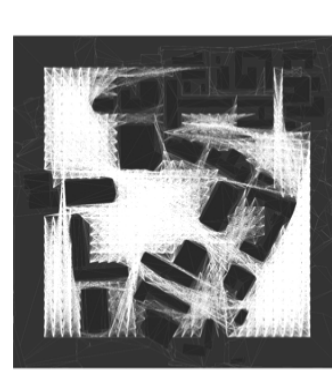

(a) Image of 3D isovist graph by orthographical projection

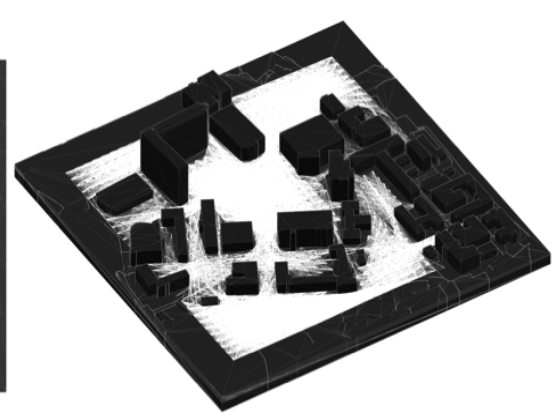

(b) Image of 3D isovist graph by isometric view
Fig.9 Image of 3D isovist graph in FU campus geography Model

\subsection{NS : 近隣サイズの比較}

NS の分布を 2D と 3D それぞれカラーマップに示す(Fig.10(a)(b)). 2D では, 図の中心から放射線状に NS の值が高いエリアが形成され ているが, $3 \mathrm{D}$ では地盤面 $18 \mathrm{~m}$ 窪みの底の部分は, 標高 $25 \mathrm{~m}$ の窪み の縁の部分よりも NS の值が低い。これは, 標高が高くなる程, 視界 の領域が広がるという一般的な経験則とも一致し, より現実の歩行 者の視線の状態を示していると言える. また, 最大, 最小となる視点 の位置と, それらの視点の隣接エッジを可視化したものを示す (Fig.10(c)(d)(e)(f)). 最大值をとる視点の位置は 2D と 3D では大きく 異なり, 3D の視点の位置は標高 $24 \mathrm{~m}$ の地盤上にあるのに対して, $2 \mathrm{D}$ では標高 $21 \mathrm{~m}$ の地盤上の位置にあり, 平面上も大きく離れている. 最小值をとる視点の位置は, 両者とも同じである.

\section{$4.2 \mathrm{MD}$ ：平均最短距離の比較}

MD の分布を 2D と 3D それぞれカラーマップに示す(Fig.11(a)(b)). 仮想地形と同様に, 中心に近づくと小さくなり, 遠ざかると大きくな り, $2 \mathrm{D}$ と $3 \mathrm{D}$ で分布の変化はほとんど見られない, また, 最大, 最 小となる視点の位置と, 極值をとる視点からその他の視点への最短 経路を示す $(F i g .11(\mathrm{c})(\mathrm{d})(\mathrm{e})(\mathrm{f})) .2 \mathrm{D}$ と 3D ともに同じ視点の位置であ り，值が若干異なるのみである. 


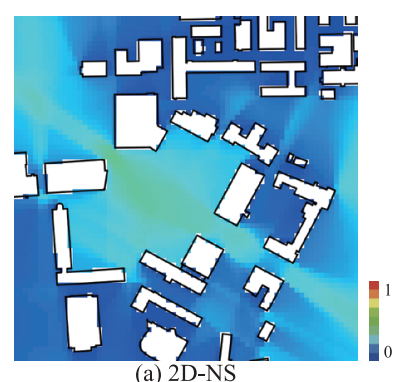

(a) $2 \mathrm{D}-\mathrm{NS}$

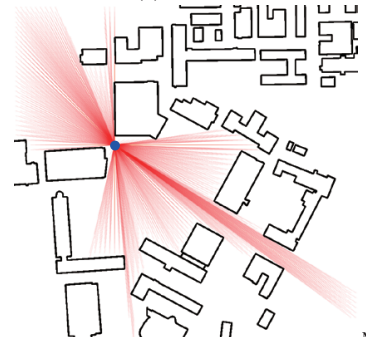

(c) 2D- NS Max

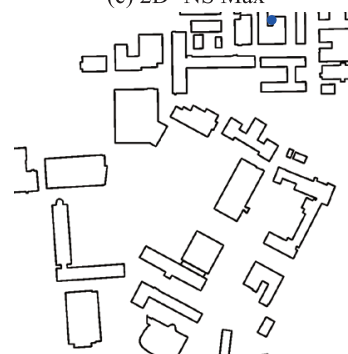

(e) $2 \mathrm{D}$ - NS Min

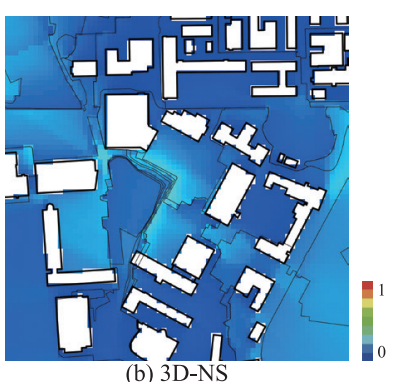

(b) $3 \mathrm{D}-\mathrm{NS}$

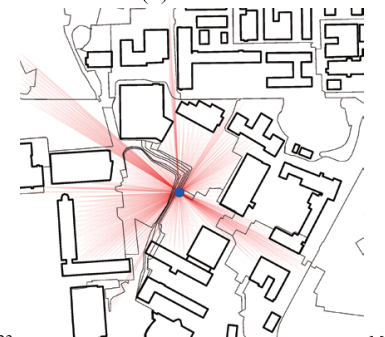

(d) 3D- NS Max
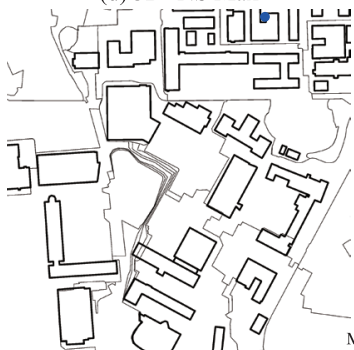

(f) 3D-NS Min

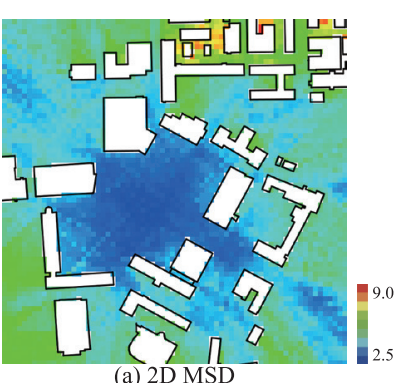

(a) $2 \mathrm{D}$ MSD

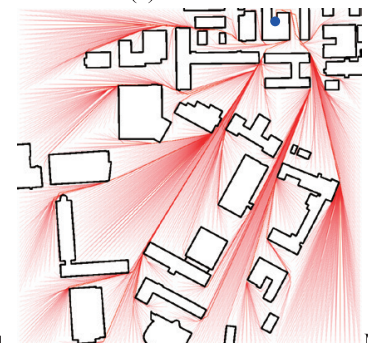

(c) 20

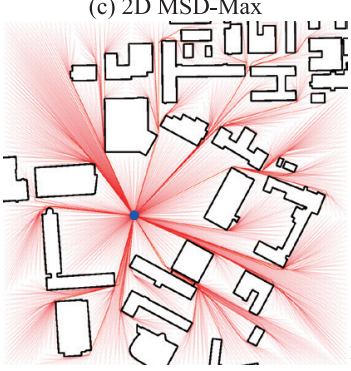

(e) 2D MSD-Min

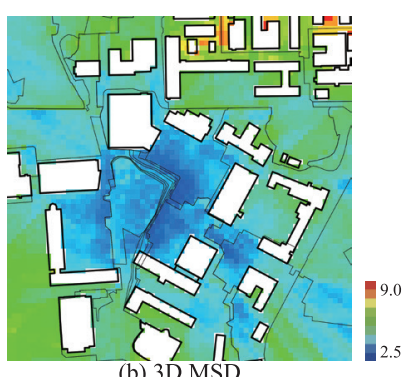

(b) 3D MSD

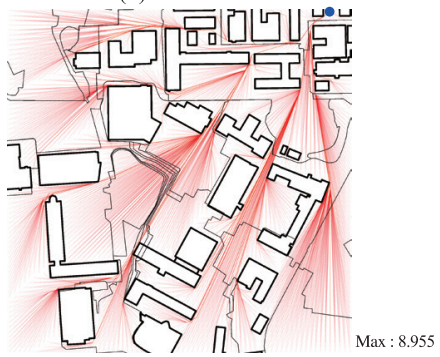

(d) $3 D$ DS

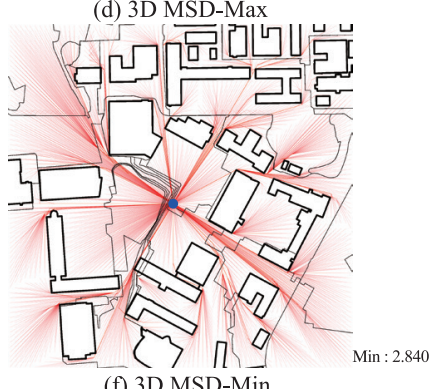

Fig.10 Result (NS) : Case-study in FU campus geography model

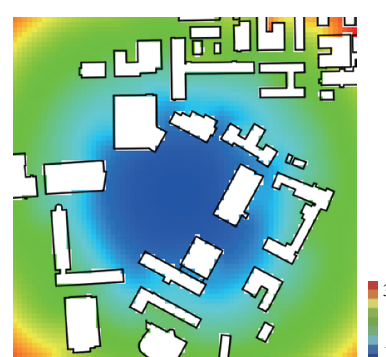

(a) $2 \mathrm{D} \mathrm{MD}$

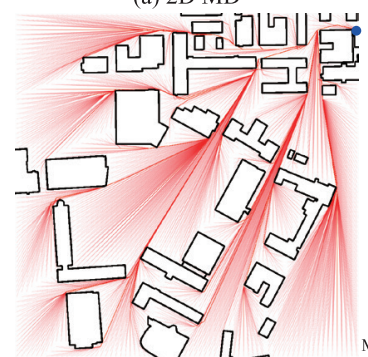

(c) 2D MD-Max

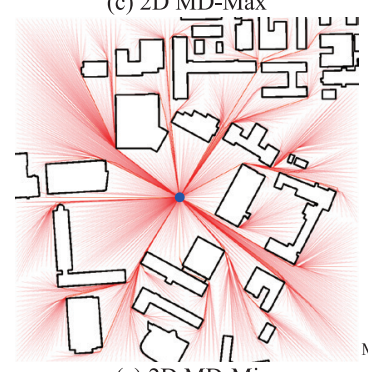

(e) 2D MD-Min

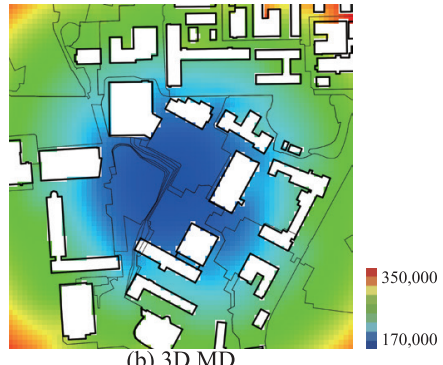

(b) $3 \mathrm{D} \mathrm{MD}$

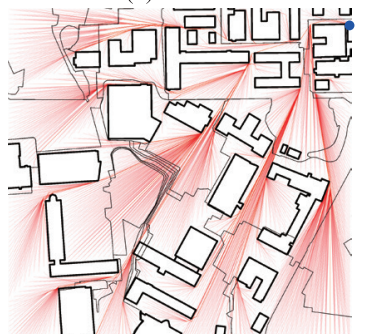

(d) 3D MD-Max

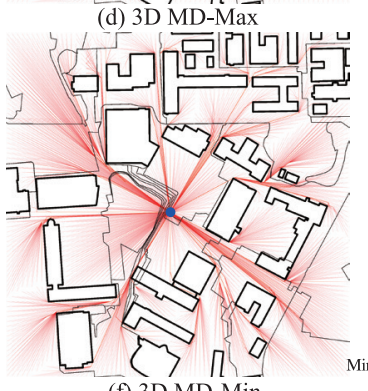

Fig.12 Result (MSD) : Case-study in FU campus geography model

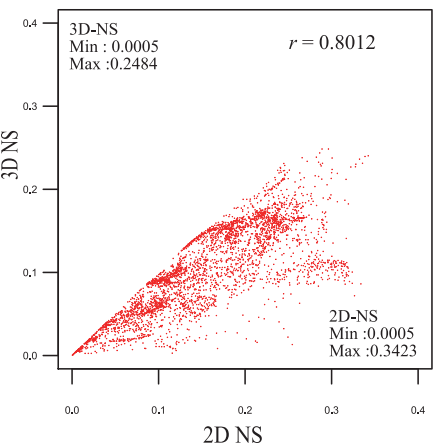

(a)

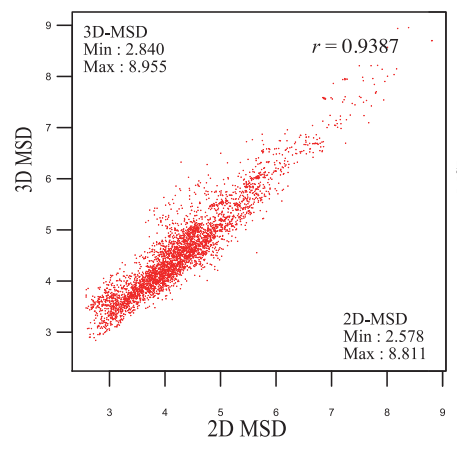

(c)

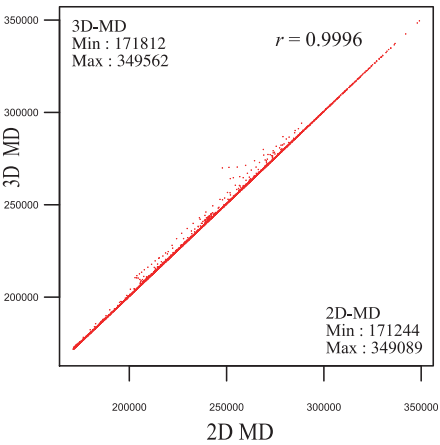

(b)

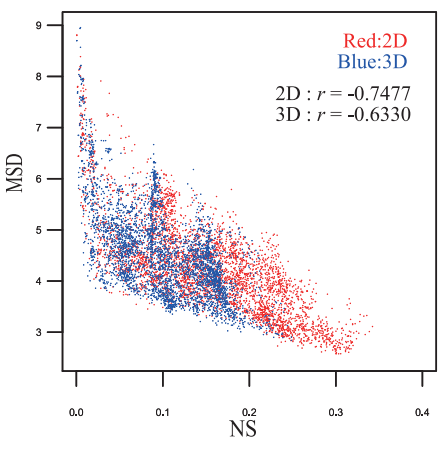

Fig.13 Scatter plots : Comparison of 2D and 3D isovist graph in FU campus geography model case-study (NS, MD, MSD)

Fig.11 Result (MD) : Case-study in FU campus geography model 


\section{$4.3 \mathrm{MSD}$ : 平均階層の比較}

MSD の分布を 2D と 3D それぞれカラーマップに示す(Fig.12(a)(b)) こちらは，2D と 3D で MSD の值の分布が明らかに異なる. NS の分 布と同様に，2D では図の中心から放射線状に MSD の值が高いエリ アが形成されているが，3D では地盤面 $18 \mathrm{~m}$ 窪みの底の部分は，標高 $25 \mathrm{~m}$ の窪みの縁の部分よりも值が高い，F大キャンパスでは，標高が 高いエリアの方が，見渡せる領域も広がり，空間の検索性も増加する と言える．また，最大，最小となる視点の位置と，極值をとる視点か らその他の視点への最短経路を示す $(F i g .12(c)(d)(e)(f))$. 最大值をとる 視点の位置は $2 \mathrm{D}$ では $18 \mathrm{~m}$ の地盤の中心付近にあるのに対して，3D では, $25 \mathrm{~m}$ の地盤の上，法面の上部エッジ付近に位置する。これらの 結果は, 崖の先端などでは, 視界が広がるという経験則にも一致する ものである.

\section{4 現実の地形における $2 \mathrm{D} \cdot 3 \mathrm{D}$ モデルの数値比較分析}

2D と 3D の比較のため, 各視点 (N=3779 点) について, NS, MD,MSD, それぞれの散布図(Fig.13(a)(b)(c))を示す。 またこれらの, 平均值, 最 大值, 最小值, $2 \mathrm{D}$ と $3 \mathrm{D}$ の相関係数を Table 3 に示寸. Fig.13 と Table 3 から, 2D と 3D の比較を行うと, NS の平均值は 3D の方が低く, $\mathrm{MD}$ の平均值は $2 \mathrm{D}$ と $3 \mathrm{D}$ とでほぼ等しく $\mathrm{MSD}$ の平均值は 3D の方 が高い.これは仮想地形のケーススタディーと同じ結果である.また, それぞれの指標の相関係数は, NS は $r \fallingdotseq 0.80$, MD は $r \fallingdotseq 0.99$, MSD は $r \fallingdotseq 0.93$, と高い. NS と MSD の関係においては，散布図 (Fig.13(d))から 3D よりも2D の方が負の相関が強い.この分析結果か ら, 数值的には NS や MSD の指標において $2 \mathrm{D}$ と $3 \mathrm{D}$ 相関性が見ら れるものの, カラーマップを見ると, 䆶みの地形付近の值の分布に明 らかな違いが見られる.これは, カラーマップによって, 数值のみか らは把握できない空間的特徴を捉えることが可能になることを示し ている.

Table3 Numerical comparison of 2D and 3D isovist graph in FU campus geography model case-study (NS, MD, MSD)

\begin{tabular}{l|c|c|c|c|c|c}
\hline & \multicolumn{2}{|c|}{ NS } & \multicolumn{2}{c|}{ MD $(\mathrm{mm})$} & \multicolumn{2}{c}{ MSD } \\
& 2D & 3D & 2D & 3D & 2D & 3D \\
\hline Mean & 0.1539 & 0.1019 & 235,953 & 236,698 & 4.273 & 4.562 \\
\hline Max & 0.3423 & 0.2484 & 349,089 & 349,562 & 8.811 & 8.955 \\
\hline Min & 0.0005 & 0.0005 & 171,244 & 171,812 & 2.578 & 2.840 \\
\hline$r$ & \multicolumn{2}{|c|}{0.8012} & \multicolumn{2}{c|}{0.9996} & \multicolumn{2}{c}{0.9387} \\
\hline
\end{tabular}

\section{5.まとめ}

\section{1 本研究の成果}

本研究では, isovist graph を 3 次元に展開する手法の開発を行い, これを仮想地形と，現実のキャンパス空間に適用し，2D と 3D の isovist graph で, 評価值がどのように異なるのか, カラーマップによ る視覚化や, 数值評価によって確認することができた. また, 起伏 のある地形に対して 2D isovist graph で解析を行った場合, 実際の感 覚と乘離した結果となりかねないことを示した. 3D isovist graph で は，地形の影響が人間の可視領域に大きな影響を与えていることを 明らかにすることができ，空間評価ッールとしての有効性が実証さ れた。特に MSD の指標のシミュレーション結果を見ると，人間の 直感では予測しにくい微妙な場の変化を把握することが可能となる.

さらに, 本研究では開発した解析システムによって, 大学のキャ ンパスデザインへの応用を念頭にしたシミュレーションを行い. 3D isovist graph の応用利用の可能性を示した， F 大のような起伏のある キャンパスにおいて複数の建築物を配置する場合, フラットな地形 のキャンパスとは異なり, 動線計画, 軸線の設定, 建築物配置計画 において，地形の影響を考慮することが重要である。このような地 形の影響は，これまでコンター模型や 3D グラフィクスなどから， 感覚的, 経験的に判断されてきたが, 3D Isovit graph は, これらのデ ザインを検討する際の，数值的な判断根拠としても活用できる可能 性がある。

また，本解析システムは，2D isovist graph の解析システムに，3D の衝突判定を加えるだけで, 簡単に拡張可能であるだけでなく, 様々 なモデルを読み込んで応用が可能で，デザインのためのツールとし ても汎用性が高く，他の様々な事例にも応用できる可能性がある.

\section{2 今後の課題}

本研究では, 計算機の処理速度によって, 視点の数や範囲が限定 された．視点 $n$ の数を増やしていくと，完全グラフのダイクストラ 法による計算アルゴリズムを用いているため，枝数が $n$ に近く処理 速度が $\mathrm{O}\left(n^{2} \log n\right)$ となり処理効率が悪い. この技術的な問題を解決 できれば,さらに広範囲かつ視点密度の高い解析が行うことができ， ツールとして汎用性がさらに増すことになる。 また，キャンパスデ ザインなどの現場においては，「見える見えない」の視線の関係と，

「行ける行けない」の歩行者の動線ネットワークが，有機的に重な り合っているかが，分かりやすく，歩きやすいキャンパス形成のキ 一ポイントになると考えられる. 今後は，歩行者の動線ネットワー クと 3D isovist graph を重衫合わせて評価する手法検討していく.

\section{謝辞}

本研究は科研費基盤（C） 16K06676 の助成を受けたものです.

参考文献

1) Benedikt, M. L. : To take hold of space : isovists and isovist fields, Environment and Planning B : Planning and design, Vol.6, No.1, pp.47-65, 1979.3

2) Kitagawa, K., Hayase, Y., Kondo, S., Zhang, J., Jiang, Y., \& Wakayama, S. : A study on architectural plan description and evaluation with" sight-depth" The space composition of the modern houses in consideration of the wall and the window, Journal of Architecture, Planning and Environmental Engineering (Transactions of AIJ), Vol.64, No.522 pp.187-194 , 1999.8 (in Japanese) 北川啓, 早瀬幸彦, 近藤正一, 張健, 姜湧, 若山滋 : 「視深度」による建築 平面記述 ・評価の 研究. 壁と開口部を考慮した近代住宅作品の空間構 成, 日本建築学会計画系論文集, 第 64 巻, 第 522 号, pp187-194, 1999.8

3) Hillier, B., Penn, A., Hanson, J., Grajewski, T., \& Xu, J.: Natural movement: or, configuration and attraction in urban pedestrian movement, Environment and Planning B: planning and design, Vol.20, No.1, pp.29-66, 1993.2

4) Turner, Alasdair, et al.: From isovists to visibility graphs : a methodology for the analysis of architectural space, Environ Planning B, Vol.28, No.1, pp.103-121, 2001.2

5) Turner, Alasdair : Depthmap 4: a researcher's handbook, Bartlett School of Graduate Studies, University College London, 2004

6) Yang, P. P. J., Putra, S. Y., \& Li, W. , Viewspshere: a GIS-based 3D visibility analysis for urban design evaluation. Environment and Planning B: Planning and Design, Vol.34, No.6, pp.971-992, 2007.12

7) Morello, E., \& Ratti, C. A digital image of the city: 3D isovists in Lynch's urban analysis. Environment and Planning B: Planning and Design, Vol.36, No.5, pp.837-853, 2009.1.

8) Bhatia, S., Chalup, S. K., \& Ostwald, M. J. : Analyzing architectural 
space: identifying salient regions by computing $3 \mathrm{D}$ isovists, In Conference proceedings. 46th annual conference of the architectural science association (AN-ZAScA), Gold Coast, QLD, 2012.11

9) Varoudis, T., \& Psarra, S.: Beyond two dimensions: architecture through three dimensional visibility graph analysis, The Journal of Space Syntax, Vol.5, No.1, pp.91-108, 2014.8

10) Shinya, M. : Spatial Analysis using 3D-Isovist-Graph, Summaries of Technical Papers of Annual Meeting, Architectural Institute of Japan, F-1, pp.1021-1022, 2017.7 (in Japanese)

宮崎慎也：3D isovist graph を用いた空間解析，日本建築学会大会学術 講演梗概集, F-1 分冊, pp.1021 1022, 2017.7

11) Isoda, S. Morozumi, M., \& Iki, K. : A model to evaluate negative influence of large building development on landmark visibility, Journal of Architecture, Planning and Environmental Engineering (Transactions of AIJ), Vol.59, No.456, pp.163-169, 1994.2 (in Japanese)

磯田節子, 両角光男, 位寄和久：ランドマークの可視・不可視領域に着目 した大規模建築物の影響評価モデルの検討, 日本建築学会計画系論文集, 第 59 巻, 第 456 号, pp.163-169, 1994.2

12) Hirose, H., Shimokawa, Y. : Development of tool analyzing geometric appearance feature of architectural space using gaze vector array by Fibonacci lattice, Journal of Architecture and Planning(Transactions of AIJ), Vol.83, No.750, pp.1611 1621, 2018.8 (in Japanese) 廣瀬寛騎, 下川雄一：フィボナッチ格子による視線ベクトル配列を用い た建築空間の視界幾何特性分析ツールの開発, 日本建築学会計画系論文 集, 第 83 巻，第 750 号, pp.1611-1621, 2018.8

13) Fujii, T., Yamada, S., Hirose, T. , \& Oikawa, K. : Measurement of the ratio of visible green spaces in the omnidirectional field of vision using CG models and their potential applications, AIJ Journal of Technology and Design, Vol.19, No.43, pp.1067 1072, 2013.10 (in Japanese) 藤井健史, 山田悟史, 廣瀬徳郎, 及川清昭: CG モデルによる全方位緑視 率の計量手法とその応用可能性, 日本建築学会技術報告集, 第 19 巻, 第 43 , pp.1067-1072, 2013.10

14) Masuda, N., Konno, N. : Fukuzatsu-Network - Kiso kara Ouyo made (Complex Networks - from the basics to the application - ), Kindaikagakusya, 2010 (in Japanese)

増田直紀, 今野紀雄 : 複雑ネットワークー基礎から応用までー, 近代科学 社, 2010

\section{注}

注 1 ) 本研究では, G.L+1,500mm の位置にノードを配置する.したがって, 3D isovist graph とは，G.L.+1,500 mm 上の仮想面上に設定される視点と それらをつなぐ視線のネットワークであり, このグラフが解析対象と なる.

注 2 ）本研究では，NS は G.L.+1,500mm 上の仮想面上に設定する視点とそれ らをつなぐ視線ネットワーク上の可視範囲を示寸指標である．視点か ら天空に向けて放射状に広がる，一般的な 3D の視線ベクトルとは異 なり, 3 次元的な視界の広がりや, 天空の広さ示寸指標ではない.

注 3 ) 近隣サイズ (次数中心性) は視点間の距離, 2 次リンク以降のノードが 考慮されないため，グラフの端のノードなど一般的に想像される中心 とは異なる場所が高くなることがある.MD は視線ネットワーク全体 の中心を求めるための指標で，一般的に想像される視覚ネットワーク の中心を特定でき, キャンパス全体の視環境の構造が把握でき, キャ ンパス計画においても重要な指標になる.

注 4 ）地形が 3D と 2D で, 中心の位置が大幅に異なる場合も想定されるので 3 次元的な視点の位置を考慮する意義は大きいと考えられる.

注 5 ) 視認性は距離によって減衰するが，大きなサイン，建物，人間，の有無 や，そこに行けるか行けないかなどを判断する程度の場合, 一般的な キャンパスの範囲においては距離による視認性の減衰は考慮しなくて も良いものと仮定している.また, 距離を考慮しないことで, 視線ネッ トワーク構造をより明示的に可視化することができ, キャンパス計画 を行う上で，よりクリアに空間構造を理解できる.

注 6 ) 本研究においてはJAVA 言語によって, 3D isovist graph の解析プラッ トフォームを開発し, Eclipse 上で実行している.

注 7 ) Fig.3 では, グラフのエッジを見やすくするため, 視点の間隔 $10,000 \mathrm{~mm}$
とした時の 3D isovist graph を可視化している.

注 8 ） Fig.9 では視点の間隔 16,000 $\mathrm{mm}$ とした時の 3D isovist graph を可視化し ている.

注 9 ) 計算処理が 24 時間内で終了することを目処に視点の密度を設定してい る.なお，計算機のスペックは，プロセッサ Intel Core i97900XCPU@3.30GHz, RAM 64.0GB である. 


\title{
DEVELOPMENT OF SYSTEM FOR 3D ISOVIST GRAPH ANALYSIS
}

\author{
Shinya MIYAZAKI*1 \\ ${ }^{* 1}$ Assist. Prof., Dept. of Architecture, Fukuoka Univ., Ph.D. in Eng.
}

This paper develops 3D isovist graph analysis system by expanding 2D isovist graph system which has been developed for urban design analysis tool. 2D isovist graph has been assumed to be humans's isovist area as a network of isovist edges on a plane parallel to the flat ground. $3 \mathrm{D}$ isovist graph enables to evaluate the space with a geography which has height difference. For this purpose, at first, it is tried to clarify the difference between 2D isovist graph and 3D isovist graph by the case-study using virtual geography model with numerical index as NS(Neighborhood Size), MD(Mean Distance), MSD(Mean Step Distance), which are popular index as well in graph theory analysis. The difference between 2D and 3D isovist graph is verified by color maps and scatter plots and numerical result of these index. Furthermore, by applying this model into real geography data of a university campus, it is confirmed that $3 \mathrm{D}$ geography influences people's sight in the campus quantitatively. Then the effectiveness of the $3 \mathrm{D}$ isovist graph in practical campus design field is verified.

As the result of the first case-study using virtual geography shows clear difference between $2 \mathrm{D}$ and $3 \mathrm{D}$ isovist graph according to the verification of color maps, scatter plots and numerical values of three index. Second case-study with real geography in a university campus which has height difference also shows a difference between 2D and 3D isovist graph. Comparing correlation coefficient of NS and MSD value both 2D and 3D isovist graph, few conspicuous disparities are found between both. However, conspicuous disparity between 2D and 3D are found from the color maps. Moreover, there are differences of position of Max and Min value of the index comparing both 2D and 3D. Although the position of Min MSD value in 2D isovist graph is in the center of bottom ground surface of the geography, the position by using 3D space model analysis is around the edge of slope faced on $25 \mathrm{~m}$ level from the sea . This result shows that $3 \mathrm{D}$ isovist graph can find more certain position along with empirical laws than $2 \mathrm{D}$.

From the results obtained in these case-studies, when we use 2D isovist graph analysis though its actual geography includes height difference, we will have a risk of misunderstanding actual condition of humans' sights. This also gives evidence of effectivity of $3 \mathrm{D}$ isovist graph. The detailed influence of the geography which is shown in MSD value is found quantitively and graphetically by using 3D isovit graph. These influences which are shown in MSD have been instinctively expected using such as contour models and computer graphics in practical campus design field. 3D isovist graph analysis gives more certain quantitative evidence for decision of design.

Improving the algorithm of Dijkstra's method enables plotting more points and making larger and higher dense maps of 3D isovist graph. This makes it possible to expand the application field of this system for larger area, for example, regional design and urban design. 